\title{
ALPHAVIRUS REPLICON PARTICLES ACTING AS ADJUVANTS PROMOTE CD8+ T CELL RESPONSES TO CO-DELIVERED ANTIGEN
}

\author{
Joseph M. Thompson ${ }^{\mathrm{a}, \mathrm{b},{ }^{*}, \dagger}$, Alan C. Whitmore ${ }^{\mathrm{b}}$, Herman F. Staats $^{\mathrm{c}}$, and Robert E. \\ Johnston ${ }^{\mathrm{a}, \mathrm{b}}$ \\ aDepartment of Microbiology and Immunology, University of North Carolina, Chapel Hill NC \\ 27599 \\ ${ }^{b}$ Carolina Vaccine Institute, University of North Carolina, Chapel Hill NC 27599 \\ 'Department of Pathology, and Human Vaccine Institute, Duke University Medical Center, \\ Durham NC 27710
}

\begin{abstract}
Alphavirus replicon particles induce strong antibody and $\mathrm{CD} 8^{+} \mathrm{T}$ cell responses to expressed antigens in numerous experimental systems. We have recently demonstrated that Venezuelan equine encephalitis virus replicon particles (VRP) possess adjuvant activity for systemic and mucosal antibody responses. In this report, we demonstrate that VRP induced an increased and balanced serum IgG subtype response to co-delivered antigen, with simultaneous induction of antigen-specific IgG1 and IgG2a antibodies, and increased both systemic and mucosal antigenspecific $\mathrm{CD}^{+} \mathrm{T}$ cell responses, as measured by an IFN- $\gamma$ ELISPOT assay. Additionally, VRP further increased antigen-specific $\mathrm{T}$ cell immunity in an additive fashion following co-delivery with the TLR ligand, CpG DNA. VRP infection led to recruitment of CD8 ${ }^{+} \mathrm{T}$ cells into the mucosal compartment, possibly utilizing the mucosal homing receptor, as this integrin was upregulated on $\mathrm{CD}^{+} \mathrm{T}$ cells in the draining lymph node of VRP-infected animals, where VRPinfected dendritic cells reside. This newly recognized ability of VRP to mediate increased $\mathrm{T}$ cell response towards co-delivered antigen provides the potential to both define the molecular basis of alphavirus-induced immunity, and improve alphavirus-based vaccines.
\end{abstract}

\section{Keywords}

viral adjuvants; viral vaccine vectors; cell-mediated immunity

\section{INTRODUCTION}

To date, vaccination is the most effective strategy for protection against morbidity and mortality associated with infectious agents [1]. The exact immunological mechanisms which serve as the critical protective factor/s vary widely depending upon the specific pathogen

\footnotetext{
(C) 2008 Elsevier Ltd. All rights reserved.

*To whom correspondence should be addressed: drjmthompson@gmail.com.

†Current Address: Department of Immunobiology, Yale University School of Medicine, New Haven, CT 06520

Publisher's Disclaimer: This is a PDF file of an unedited manuscript that has been accepted for publication. As a service to our customers we are providing this early version of the manuscript. The manuscript will undergo copyediting, typesetting, and review of the resulting proof before it is published in its final citable form. Please note that during the production process errors may be discovered which could affect the content, and all legal disclaimers that apply to the journal pertain.
} 
[2]. Likewise, the nature and makeup of the particular vaccine shapes the qualitative and quantitative aspects of the host immune response. In general terms, protection is traditionally associated with either the induction of a neutralizing antibody response, the induction of a cell mediated immune response, or both [2]. There are a number of examples in which the immune correlates of protection have been identified (reviewed in [2]); however, correlates have not been defined for important pathogens, such as human immunodeficiency virus (HIV) [3, 4]. Therefore, vaccination regimens capable of stimulating both a broadly active antibody response and cell mediated immunity represent an opportunity to interdict in the spread of such diseases.

Immunogen delivery systems based upon the alphaviruses have proven to be efficient inducers of both neutralizing antibody responses and cell mediated immune responses to multiple antigens, including HIV antigens, expressed from the viral genome (reviewed in [5-11]). Alphavirus vectors derived from Sindbis virus, Semliki forest virus (SFV), and Venezuelan equine encephalitis virus (VEE) have generated the most promising results to date and all three of these systems are actively under investigation as candidate HIV vaccine vectors in several laboratories. Replicon particles harbor a modified genome; the viral nonstructural genes, which encode the proteins required to replicate the genomic RNA, are expressed from the $5^{\prime}$ two thirds of the genome, while the viral 26S subgenomic promoter catalyzes the transcription of the remainder of the genome into a subgenomic mRNA [12]. The genome of replication-competent virus contains the viral structural genes, the capsid and E1 and E2 glycoprotein genes, expressed from the $26 \mathrm{~S}$ promoter. This structural gene cassette has been replaced with a cloned antigen of interest in the vaccine replicon constructs [13]. In order to package these defective replicon genomes into replicon particles, the replicon RNA is co-electroporated into permissive cells with two helper RNAs which together drive the expression of the structural components in trans. However only the replicon RNA is incorporated into replicon particles, as the viral-specific packaging signal is deleted from the helper constructs [14]. VEE replicon particles (VRP) are currently under development as an HIV vaccine platform in part for the ability to stimulate cell-mediated immune responses directed against expressed antigens [15-19].

$\mathrm{CD}^{+} \mathrm{T}$ cells are activated following interaction with antigen presenting cells (APCs) that present on their surface peptide fragments in the context of major histocompatibility complex I (MHC I), along with co-stimulatory molecules [20]. Two pathways of antigen loading into MHC class I molecules have been described. In the endogenous pathway, peptide fragments derived from cytosolic proteins are transported into the endoplasmic reticulum (ER) via the transporter associated with antigen processing (TAP) molecule [21] and then transported to the cell surface for presentation to cognate $\mathrm{CD} 8^{+} \mathrm{T}$ cells [22]. In addition to the endogenous pathway, a separate pathway of exogenous antigen loading, termed cross-presentation, also has been identified, which directs exogenous antigens into the class I pathway in a TAP-independent manner, providing a means for the activation of $\mathrm{CD} 8^{+} \mathrm{T}$ cell responses against pathogens which do not directly infect APCs [23, 24].

Some infectious agents directly infect APCs, which contain a number of cellular pathogen recognition molecules. For example, toll-like receptors (TLRs) are pattern recognition receptors which recognize conserved motifs, or pathogen associated molecular patterns (PAMPs) [25] and play a critical role in shaping both innate and adaptive immune responses $[26,27]$. Delivery of numerous TLR ligands promotes pro-inflammatory cytokine secretion and cross-priming of $\mathrm{CD}^{+} \mathrm{T}$ cells [28].

We have recently identified a novel activity of VRP, that they act as adjuvants for both systemic and mucosal antibody responses to antigens that are simply mixed with VRP encoding either an irrelevant transgene or no transgene at all [29]; however, $\mathrm{CD} 8^{+} \mathrm{T}$ cell 
adjuvant effects were not evaluated in those studies. When VRP are utilized as expression vectors, all VRP-infected cells also contain the expressed antigen. Following delivery of antigen mixed with VRP adjuvants, both VRP and antigen are likely to be sequestered to the same draining lymph node. However, antigen may or may not be taken up by the same dendritic cells (DCs) that are targets of VRP infection [30]. Therefore, it is theoretically possible that co-delivered antigen could be processed in a very different manner than antigens expressed from the VRP genome, leading to a discinct effect on $\mathrm{CD} 8^{+} \mathrm{T}$ cell activation.

In this report we have assessed the ability of VRP, either alone or in combination with a representative TLR ligand (CpG DNA), to activate cell-mediated immunity to a co-delivered antigen. VRP infection produced an adjuvant effect, promoting increased systemic and mucosal $\mathrm{CD} 8^{+} \mathrm{T}$ cell responses to co-delivered protein antigen, and an additive increase in the presence of CpG DNA, as measured by IFN- $\gamma$ secretion. Interestingly, nonmucosal VRP delivery resulted in a recruitment of $\mathrm{CD} 8^{+} \mathrm{T}$ cells into the mucosal compartment, as well as an increase in expression of the mucosal homing receptor on $\mathrm{CD} 8^{+} \mathrm{T}$ cells in the peripheral draining lymph node (DLN). Taken together these results suggest that VRP promote not only increased antibody responses [29], but also $\mathrm{T}$ cell responses to co-delivered antigens in both the systemic and mucosal compartments.

\section{MATERIALS AND METHODS}

\subsection{VEE replicon particles}

The VRP utilized in this report were prepared and packaged as previously described [14, 31]. Briefly, in vitro-transcribed replicon RNA, along with two defective helper RNAs, which express the viral structural genes in trans, were co-electroporated into BHK-21 cells. Only the replicon RNA was packaged into particles as the viral-specific packaging signal is absent from the helper RNAs. In this study, we have utilized a replicon which lacks a functional transgene downstream of the 26S promoter (null VRP) [29]. All replicon particles were packaged in the wild-type VEE (V3000) envelope [32].

\subsection{Animals and immunizations}

Seven-to-10-week-old female BALB/c or C57BL/6 mice were immunized in a $0.01 \mathrm{ml}$ volume in the rear footpad(s) as previously described [29]. Animals were immunized at week 0 and week 4 with antigen alone or antigen co-inoculated with either VRP and/or CpG DNA as an adjuvant. Chicken egg albumin (OVA) was purchased from Sigma and CpG DNA (ODN 1826) was purchased from Invivogen. Diluent consisted of low endotoxin, filter-sterilized PBS. For peptide immunization experiments, animals were immunized in both rear footpads in a $0.02 \mathrm{ml}$ volume with the class I-restricted OVA peptide (SIINFEKL, New England Peptide) at weeks 0, 4, and 8.

\subsection{Serum collection}

Collection of serum from immunized animals was performed as previously described [29]. Blood was harvested either from the tail vein, following cardiac puncture, or from the submandibular plexus from individual animals and sera collected following centrifugation in microtainer serum separator tubes (Becton Dickinson).

\subsection{Cell preparation and flow cytometric analysis}

For preparation of single cell suspension from the DLN, DLNs were harvested from immunized animals and each lymph node was disrupted with a razor blade and a hemostat, and single cell suspensions were created by agitating each lymph node in complete RPMI medium [RPMI medium 1640 containing 10\% (vol/vol) FBS, $2 \mathrm{mM} \mathrm{L-glutamine,} 50 \mu \mathrm{g} / \mathrm{ml}$ 
gentamicin, 100 units $/ \mathrm{ml}$ penicillin, $100 \mu \mathrm{g} / \mathrm{ml}$ streptomycin, and $15 \mathrm{mM}$ Hepes] containing $2.5 \mathrm{mg} / \mathrm{ml}$ Collagenase A (Roche Applied Science) and $17 \mu \mathrm{g} / \mathrm{ml}$ DNase I (Roche Applied Science) for 30 minutes at $37^{\circ} \mathrm{C}$. Single cell suspensions were then stained with antibodies directed against CD3, CD19, CD45 (B220), CD11c, CD11b (all purchased from ebioscience) as well as $a_{4} \beta_{7}$ integrin (LPAM-1, clone DATK32, BD Pharmingen) and CCR9 (R\&D Systems) and examined on a Becton Dickinson Facscaliber Flow cytometer and analyzed using Cellquest software.

For preparation of single cell suspensions from the spleen, whole spleens were disrupted between frosted glass slides, and red blood cells were lysed following addition of ammonium chloride buffer. Cells were pooled from two animals, washed and banded on a Lympholyte-M density gradient (Accurate), and counted as described [29].

Nasal lymphocytes were also prepared as previously described [29]. Briefly, nasal tissue was physically and enzymatically disrupted by incubation at $37^{\circ} \mathrm{C}$ for $2 \mathrm{hrs}$ in a $50 \mathrm{ml}$ Erlenmeyer flask in complete R-10 containing $2.5 \mathrm{mg} / \mathrm{ml}$ Collagenase A (Roche), $17 \mu \mathrm{g} / \mathrm{ml}$ DNase I (Roche) and glass beads. Following digestion, cells were filtered through a $40 \mu \mathrm{m}$ cell strainer (BD Falcon), washed, resuspended in 44\% Percoll (Amersham) and layered on Lympholyte-M. Banded cells were harvested, washed, and counted. Cells were pooled from two animals and typical yields were approximately $2.5 \times 10^{5}$ to $1 \times 10^{6}$ cells per animal.

\subsection{Enzyme Linked Immunosorbant Assay (ELISA)}

ELISAs for OVA-specific antibodies were performed on serum as previously described [29]. Briefly, an OVA solution (1 mg/ml in PBS) was incubated in 96-well plates (Costar) overnight at $4{ }^{\circ} \mathrm{C}$ and subsequently blocked overnight with blocking solution [PBS $1 \mathrm{x}$ Sigmablock (Sigma)] at RT. Plates were next incubated at room temperature (RT) overnight with 2-fold serial dilutions of individual samples. Plates were washed and incubated for $1 \mathrm{hr}$ with horseradish peroxidase-conjugated secondary goat anti-mouse IgG1 or IgG2a chainspecific antibodies (Southern Biotechnology Associates or Sigma). Finally, plates were again washed, and developed following delivery of $O$-phenylenediamine dihydrochloride substrate. Antibody endpoint titers are reported as the reciprocal of the highest dilution that resulted in an OD450 $\searrow$.2. Data are presented as the geometric mean \pm standard error of the mean (SEM).

\subsection{IFN-Y enzyme-linked immunospot assay (ELISPOT)}

An IFN- $\gamma$ ELISPOT assay was employed to quantitate OVA-specific IFN- $\gamma$-secreting cells, present in both the spleen and nasal epithelium of immunized mice. Nitrocellulose membrane plates (96 well; Millipore) were incubated with $5 \mu \mathrm{g} / \mathrm{ml}$ of an anti-IFN- $\gamma$ antibody (AN18, Mabtech) in sodium bicarbonate buffer ( $\mathrm{pH}$ 9.6) overnight at $4^{\circ} \mathrm{C}$. Plates were then washed and blocked for 2 hrs with complete R-10 (10\% fetal bovine serum) at $37^{\circ} \mathrm{C}$. Single cell suspensions in R-10 $\left(1 \times 10^{5}\right.$ to $2.5 \times 10^{5}$ cells per well) from either spleen or nasal epithelium were then added to plates in duplicate and incubated in the presence and absence of the class I-restricted OVA peptide (SIINFEKL, New England Peptide) for $24 \mathrm{hrs}$. Cells were removed from plates, plates were washed, a biotinylated anti-IFN- $\gamma$ antibody (R4-6A2, $1 \mu \mathrm{g} / \mathrm{ml}$, Mabtech) was added to the plates, and the plates were incubated for 18 hours at $4{ }^{\circ} \mathrm{C}$. Membranes were again washed, incubated with a streptavidin-alkaline phosphotase conjugate for $2 \mathrm{hrs}$ at RT. Plates were washed, and spots were developed following addition of BCIP/NBT substrate. Spots were enumerated with a computerized ELISPOT plate reader (Immunospot). Assay background values were obtained following incubation with either no peptide or an irrelevant peptide and were subtracted from values obtained with the OVA peptide. Data are normalized to the number of antigen-specific IFN$\gamma$-secreting-cells per $10^{6}$ cells. 


\subsection{Intracellular cytokine staining}

Single cell suspensions were prepared from spleen and nasal epithelium as described above. $2 \times 10^{5}$ to $2 \times 10^{7}$ cells were incubated for $6-8$ hours in media containing $10 \mu \mathrm{g} / \mathrm{ml}$ of Brefeldin A alone, media containing Brefeldin A and $2 \mu \mathrm{g} / \mathrm{ml}$ of the class I-restricted OVA peptide (SIINFEKL), $2 \mu \mathrm{g} / \mathrm{ml}$ of an irrelevant peptide, or $5 \mu \mathrm{g} / \mathrm{ml}$ conconavalin A. Cells were then washed and stained with antibodies against cell surface markers (CD8, CD4, CD3, etc) for 30 mins. Cells were washed, fixed and permeabilized (Bectin Dickinson cytofix cytoperm), and stained with an antibody against IFN- $\gamma$ (Mabtech). Cells were washed and stored at $4{ }^{\circ} \mathrm{C}$ prior to analysis by flow cytometry.

\subsection{Pentamer staining}

Single cell suspensions prepared from animals immunized with the class I OVA peptide (SIINFEKL) were analyzed for the presence of OVA-specific cells via cell surface staining with antibodies against $\mathrm{CD} 3, \mathrm{CD} 8$, and the $\mathrm{K}^{\mathrm{b}}$-restricted SIINFEKL pentamer (Proimmune) according to manufacturer guidelines. Stained cells were examined on a Becton Dickinson Facscaliber Flow cytometer and analyzed using Cellquest software. Data are reported as the percentage of $\mathrm{CD}^{+}, \mathrm{CD}^{+}$cells which also stain positive with the OVA pentamer. Values are presented as geometric mean $+/-$ SEM.

\subsection{Statistical Analysis}

Antibody titers and cytokine values were evaluated for statistically significant differences by either the ANOVA or Mann-Whitney test (GraphPad INSTAT). Results are reported without adjustment for multiple comparisons. A p value of $₫ 0.05$ was considered significant.

\section{RESULTS}

\subsection{VRP adjuvants promote a balanced Th1/Th2 antibody profile}

We have previously demonstrated the ability of VRP to increase the systemic and mucosal antibody response to co-delivered antigens (Thompson et al., In Press; [29]). Additionally, both Th1 and Th2 cytokines were induced in the VRP-draining lymph node at early times following VRP delivery (Thompson et al., In Press;[33]). Here we have further characterized the antigen-specific serum IgG antibody profile for the presence of $\mathrm{IgG} 1$ and $\mathrm{IgG} 2 \mathrm{a}$ antibodies as an indirect measure of the Th1/Th2 cytokine profile following VRP immunization. Groups of eight female Balb/c mice were immunized in the rear footpad at week 0 and week 4 with OVA alone $(10 \mu \mathrm{g})$, or OVA $(10 \mu \mathrm{g})$ mixed with either null VRP $\left(1 \times 10^{5} \mathrm{IU}\right)$ or CpG DNA $(1 \mu \mathrm{g})$. We have utilized footpad delivery here due to our extensive experience using this route in VEE pathogenesis studies. Footpad infection targets antigens to a single DLN and provides a tractable system to study the first infected cells and the effects of VRP delivery on the immune inductive tissues [30]. Two weeks following the second inoculation, sera were collected and analyzed for the presence of OVA-specific IgG antibodies by ELISA. The OVA-specific total IgG results shown in Figure 1A were previously reported in a different format in Thompson et al. [29], and are reprinted here for clarity. As shown in Figure 1A, the inclusion of null VRP in the inoculum increased the OVA-specific $\operatorname{IgG}$ antibody response by approximately 40 -fold. As expected, delivery of OVA plus CpG DNA as an adjuvant likewise induced an approximately 40-fold increase in the systemic IgG antibody response. We next analyzed the same sera for the presence of OVA-specific IgG1 and IgG2a antibodies by ELISA. Delivery of OVA alone resulted in a strong OVA-specific $\operatorname{IgG} 1$ response relative to the $\operatorname{IgG} 2$ a response, with an $\operatorname{IgG} 1$ : $\operatorname{IgG} 2 \mathrm{a}$ ratio of $>20$ (Figure 1B). In contrast, inclusion of VRP as an adjuvant significantly increased the OVA-specific IgG2a response, while simultaneously inducing an OVA-specific IgG1 antibody titer similar to that of antigen delivery alone. This resulted in a balanced $\mathrm{IgG} 1$ : IgG2a ratio of 0.8 (Figure 1B). A similarly balanced IgG1: IgG2a ratio was observed 
following delivery of OVA and CpG DNA (0.5). These results suggest that VRP co-delivery significantly alters the systemic IgG subtype profile compared to delivery of antigen alone, and results in a balanced antibody response with the production of both Th1 and Th2 IgG antibodies [34, 35]. The antibody adjuvant data presented here and in Thompson et al. [29] were derived from experiments performed in Balb/c mice; however, we have observed significant antibody adjuvant activity in several mouse strains including Balb/c, C57BL/6, and $129 \mathrm{~Sv} / \mathrm{Ev}$, suggesting that the VRP adjuvant effect is not dependent upon a specific mouse genotype (Thompson J.M. and Johnston R.E., unpublished observations).

\subsection{VRP adjuvants promote an increased cellular immune response to co-delivered soluble antigen}

To determine whether VRP possess the ability to stimulate $\mathrm{CD}^{+} \mathrm{T}$ cell responses to codelivered antigens, groups of eight female C57BL/6 mice were immunized in the rear footpad at week 0 and week 4 with OVA alone $(100 \mu \mathrm{g})$, or with OVA $(100 \mu \mathrm{g})$ mixed with null VRP $\left(1 \times 10^{5} \mathrm{IU}\right)$, CpG DNA $(1 \mu \mathrm{g})$, or both null VRP $\left(1 \times 10^{5} \mathrm{IU}\right)$ and CpG DNA $(1 \mu \mathrm{g})$ simultaneously. Two weeks following the second immunization, animals were sacrificed and single cell suspensions were prepared from the spleen, a characteristic systemic lymphoid organ, and from the nasal epithelium, a characteristic mucosal tissue. Splenocytes and nasal lymphocytes were evaluated for the presence of IFN- $\gamma$-secreting cells following stimulation with the class I-restricted OVA peptide (SIINFEKL) in an IFN- $\gamma$ ELISPOT assay. As shown in Figure 2, delivery of OVA alone resulted in low, but detectable levels of OVA-specific CD8 ${ }^{+} \mathrm{T}$ cell responses in both the spleen (Figure $2 \mathrm{~A}$ ) and the nasal epithelium (Figure 2B). This response was increased approximately 12-fold in the spleen, and 7-fold in the nasal epithelium when VRP were included as an adjuvant. CpG DNA also demonstrated a significant adjuvant effect in the systemic and mucosal compartments. When both VRP and CpG were combined as adjuvants, the OVA ELISPOT response was increased further, compared to either VRP or CpG DNA alone. Taken together, these results suggest that VRP as an adjuvant increases the $\mathrm{CD} 8^{+} \mathrm{T}$ cell response to soluble protein antigen, and that combining VRP and CpG DNA provides an additive adjuvant effect.

\subsection{VRP adjuvants promote an increased cellular immune response to co-delivered peptide antigen}

VRP may augment $\mathrm{CD} 8^{+} \mathrm{T}$ cell immunity at various stages in the $\mathrm{T}$ cell activation pathway, both upstream and downstream of antigen processing. As a first step in characterizing the $\mathrm{T}$ cell activation pathway in which VRP and CpG are active, the ability of VRP to augment $\mathrm{CD}^{+} \mathrm{T}$ cell responses was examined under experimental conditions which do not require antigen processing to individual peptides. Groups of eight female C57BL/6 mice were immunized in the rear footpad at week 0 and week 4 with $20 \mu \mathrm{g}$ OVA peptide (SIINFEKL) alone followed by a third inoculation of $10 \mu \mathrm{g}$ of peptide to maximize the $\mathrm{CD} 8^{+} \mathrm{T}$ cell response induced by peptide antigen alone. In addition, mice were immunized with OVA peptide in the same amounts, and on the same dosing schedule mixed with either null VRP $\left(1 \times 10^{5} \mathrm{IU}\right)$, CpG DNA $(1 \mu \mathrm{g})$, or both null VRP $\left(1 \times 10^{5} \mathrm{IU}\right)$ and CpG DNA $(1 \mu \mathrm{g})$. Two weeks following the third immunization, animals were sacrificed and single cell suspensions were prepared from the spleen and nasal epithelium. Splenocytes were first examined for IFN- $\gamma$ secretion by ELISPOT. As shown in Figure 3A, delivery of OVA peptide alone failed to induce significant numbers of OVA-specific IFN- $\gamma$-secreting cells in the spleen, as measured by IFN- $\gamma$ ELISPOT. However, when VRP were co-inoculated with OVA peptide, OVA-specific IFN- $\boldsymbol{\gamma}$-secreting cells were detectable in the spleen at approximately 10 -fold higher levels than present following delivery of peptide alone. A similar increase was also observed following use of $\mathrm{CpG}$ as an adjuvant. Moreover, delivery of OVA peptide in the presence of both VRP and CpG DNA resulted in a significantly stronger response than delivery of either adjuvant alone ( $\mathrm{p}<0.01)$. To further characterize the OVA-specific $\mathrm{T}$ cell 
response following peptide delivery, OVA-specific $\mathrm{CD} 8^{+} \mathrm{T}$ cells were evaluated by SIINFEKL/MHC I pentamer analysis. Delivery of OVA peptide in the presence of both VRP and $\mathrm{CpG}$ resulted in an increased proportion of OVA-specific $\mathrm{CD} 8^{+} \mathrm{T}$ cells in both the spleen (Figure 3B) and nasal epithelium (Figure 3C) compared to delivery of OVA peptide alone. However, delivery of OVA peptide in the presence of either VRP or CpG did not result in a statistically significant increase in the proportion of OVA-specific $\mathrm{CD} 8^{+} \mathrm{T}$ cells compared to delivery of OVA peptide alone. Taken together, these results suggest that VRP, in combination with $\mathrm{CpG}$ DNA, increase the antigen-specific $\mathrm{CD} 8^{+} \mathrm{T}$ cell response to peptide antigen.

\subsection{Nonmucosal VRP delivery results in increased numbers of mucosal CD8+ $\mathrm{T}$ cells}

In addition to the high dose $(100 \mu \mathrm{g})$ OVA experiments presented in Figure 2, we also employed an intracellular cytokine staining (ICS) assay for IFN- $\gamma$ following low dose (10 $\mu \mathrm{g})$ OVA administration in the presence/absence of a VRP adjuvant. Groups of eight female C57BL/6 mice were immunized in the rear footpad at week 0 and week 4 with OVA alone $(10 \mu \mathrm{g})$, or with OVA $(10 \mu \mathrm{g})$ mixed with null VRP $\left(1 \times 10^{5} \mathrm{IU}\right)$ and splenocytes and nasal lymphocytes were evaluated for the presence of IFN- $\gamma$ positive $\mathrm{CD}^{+} \mathrm{T}$ cells by ICS two weeks following the booster immunization. In this model, IFN- $\gamma^{+} \mathrm{CD} 8^{+} \mathrm{T}$ cells were essentially undetectable by ICS in the spleens of immunized animals regardless of the presence of VRP in the inoculum (data not shown). IFN- $\gamma^{+} \mathrm{CD} 8^{+} \mathrm{T}$ cells were detectable in the nasal epithelium of immunized animals; however, the presence of VRP in the inoculum did not induce a statistically significant increase compared to delivery of OVA alone (Figure $4 \mathrm{~A})$.

We next evaluated whether VRP delivery affected the number of CD8 ${ }^{+} \mathrm{T}$ cells in the nasal mucosa of immunized animals. Interestingly, inclusion of VRP in the inoculum resulted in an approximately 5 -fold increase in the proportion of viable $\mathrm{CD} 8^{+} \mathrm{T}$ cells in the nasal epithelium (Figure 4B). This effect results in an increase in the absolute number of OVAspecific $\mathrm{CD} 8^{+} \mathrm{T}$ cells in the nasal mucosa, even under conditions where the proportion of OVA-specific IFN- $\gamma$-secreting cells was not increased (Figure 4C). The proportion of CD8 ${ }^{+}$ $\mathrm{T}$ cells in the spleen was unaffected by VRP delivery (data not shown), suggesting that $\mathrm{CD}^{+} \mathrm{T}$ cells may be recruited specifically into the mucosal compartment when VRP are utilized as adjuvants.

\subsection{Nonmucosal VRP delivery upregulates the mucosal homing receptor on $\mathrm{CD}^{+} \mathrm{T}^{-}$cells in the draining lymph node}

As a first step in characterizing the recruitment of $\mathrm{T}$ cells to the mucosal surface following VRP delivery, levels of two important mucosal homing molecules, the $\alpha_{4} \beta_{7}$ integrin and CCR9 [36], were evaluated on T cells present in the DLN. Groups of female Balb/c mice were immunized in the rear footpads with OVA $(10 \mu \mathrm{g})$ in the presence and/or absence of null VRP $\left(1 \times 10^{5} \mathrm{IU}\right)$ at week 0 and week 4 and DLNs were harvested at day 1 and day 3 following the second inoculation. Single cell suspensions were created by collagenase digestion and cells were stained with antibodies against CD3, CD4, CD8, CCR9, and the $a_{4} \beta_{7}$ integrin (LPAM-1). At day 1 post boost, both $C D 4^{+} \mathrm{T}$ cells and CD $8^{+} \mathrm{T}$ cells were present in the DLN of immunized animals; however, neither CCR9 nor $\alpha_{4} \beta_{7}$ integrin was upregulated by the inclusion of VRP in the inoculum (data not shown). At day 3 post boost, CCR9 levels were not increased on either $\mathrm{CD}^{+} \mathrm{T}$ cells or $\mathrm{CD}^{+} \mathrm{T}$ cells present in the DLN (Figure 5). In contrast, the number of DLN CD8 ${ }^{+} \mathrm{T}$ cells with upregulated $a_{4} \beta_{7}$ integrin expression was increased following OVA plus VRP delivery, compared to delivery of OVA alone at day 3 . The proportion of $\mathrm{CD} 4^{+} \mathrm{T}$ cells with increased $a_{4} \beta_{7}$ integrin expression in the DLN were unaffected by VRP at the same timepoint. Together, these results suggest that 
mucosal homing molecule expression on $\mathrm{CD} 8^{+} \mathrm{T}$ cells in the DLN correlates with mucosal $\mathrm{T}$ cell adjuvant activity.

\section{DISCUSSION}

Cell-mediated immune responses play a crucial role in protecting the host from invading pathogens. Thus, the development of vaccination strategies which are capable of activating $\mathrm{CD} 8^{+} \mathrm{T}$ cells possess the potential to significantly influence the outcome of infection with harmful organisms. Viruses and viral vectors induce potent $\mathrm{CD}^{+} \mathrm{T}$ cell-mediated immunity in a number of experimental systems, and gaining a mechanistic understanding of both the immunological and virological basis of $\mathrm{T}$ cell activation may in the long run allow for the optimization of viral vectors as vaccine delivery tools.

Alphavirus expression vectors based on Sindbis virus, Semliki forest virus, and Venezuelan equine encephalitis virus induce strong $\mathrm{CD}^{+} \mathrm{T}$ cell responses against antigens which are expressed from the viral genome (reviewed in [5-11]). Under these conditions, all productively infected cells would also produce heterologous antigen, providing a means for virally-expressed proteins/peptide fragments to gain access to the MHC class I pathway in the same cells that receive viral activation signals. Here we demonstrate the ability of VRP, as an adjuvant, to induce activation of $\mathrm{CD}^{+} \mathrm{T}$ cell responses to a co-delivered antigen. This is the first formal demonstration of $\mathrm{CD} 8^{+} \mathrm{T}$ cell adjuvant activity following alphavirus delivery. Antibody adjuvant activity has been observed with attenuated VEE virus [37, 38] and with replicon particles derived from VEE [29] and Semliki forest virus [39]; however, T cell adjuvant effects were either not detected or not examined in those reports.

The mechanism(s) underlying VRP CD8 ${ }^{+} \mathrm{T}$ cell adjuvant activity are undefined at present; however, two general of models are plausible. First, it is possible that $\mathrm{T}$ cell activation results from the interaction of $\mathrm{CD} 8^{+} \mathrm{T}$ cells with APCs that were both infected by VRP and had taken up exogenous antigen by phagocytosis and/or pinocytosis. In support of this idea VRP are known to upregulate co-stimulatory molecule expression on infected mouse (Moran, T.P., Johnston, R.E., and Serody, J.S., unpublished observations) and human [40] DC cultures, and promote $\mathrm{CD}^{+} \mathrm{T}$ cell responses to antigens which are encoded in the VRP genome. Moreover, incubation of peripheral blood mononuclear cells with VRP-infected DCs in vitro significantly expands antigen-specific $\mathrm{CD}^{+} \mathrm{T}$ cells [40], suggesting that antigen-bearing, infected cells are sufficient to activate cognate $\mathrm{CD} 8^{+} \mathrm{T}$ cells.

A second non-mutually exclusive possibility is that, as VRP and OVA may target distinct APC subsets, VRP may provide an adjuvant signal for $\mathrm{CD} 8^{+} \mathrm{T}$ cell activation to uninfected, antigen-bearing APCs, possibly via the secretion of soluble mediators in the DLN.

Consistent with this idea, VRP induce the production of several inflammatory mediators in the DLN including IFN- $\beta$, TNF- $a$, IL-6, IFN- $\gamma$, RANTES, and MIP1- $\beta$ (Thompson et al., In Press; [33]) which may affect $\mathrm{CD} 8^{+} \mathrm{T}$ cell activation. Further experimentation will be required to determine the relative contributions of both direct activation and cross priming in the VRP adjuvant system. However, regardless of dependence upon co-delivery of VRP and antigen to the same cell, we suggest that VRP potentially act downstream of antigen acquisition and antigen processing, as increased IFN- $\gamma$ secretion by $\mathrm{CD} 8^{+} \mathrm{T}$ cells was observed following delivery of peptide antigen in the presence of VRP. This delivery circumvents both antigen uptake and processing to the immunogenic peptide Of note in this regard, VRP delivery alone in the presence of peptide antigen stimulated a significant adjuvant effect as measured by IFN- $\gamma$ ELISPOT, whereas only VRP co-delivery with CpG DNA resulted in an adjuvant effect as measured by pentamer staining (see Fig. 3A and 3B), which may suggest that VRP adjuvants induce the activation of antigen-specific cells more 
so than the generation antigen-specific cells per se. Further experiments are underway to test such an hypothesis.

As mentioned above, VRP specifically infect DCs in the lymph node draining the infection site [30], and preliminary experiments suggest that CD11 ${ }^{+}$DCs represent the major target of VEE infection (West, A., Whitmore, A.C., Moran, T.P., and Johnston, R.E., unpublished observations). Interestingly, CD11 $\mathrm{b}^{+} \mathrm{DCs}$ have been implicated in the induction of Th1 $\mathrm{CD}^{+} \mathrm{T}$ cell responses in several model systems [41-43], (reviewed in [26, 44]), raising the

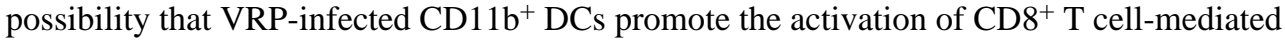
immunity by driving helper $\mathrm{CD} 4^{+} \mathrm{T}$ cells towards a Th1 phenotype in vivo. Consistent with this idea, both Th1-biased IgG2a antibodies (this report) and Th1 cytokines such as IL-12p70 and IFN- $\gamma$ were produced in VRP-infected animals (Thompson et al., In Press; Thompson, J.M., and Johnston, R.E., unpublished observations). In fact, analysis of the IgG profile (Fig. 1B) following VRP delivery suggests that VRP adjuvants predominantly stimulate a Th1-biased IgG2a response. This was a surprising finding, given that VRP also catalyze Th2 cytokine production such as IL-5 and IL-6 in VRP-infected animals (Thompson et al., In Press). Nonetheless, such an observation is consistent with an important role for Th1 $\mathrm{CD}^{+} \mathrm{T}$ cells in VRP CD8 ${ }^{+} \mathrm{T}$ cell adjuvant activity, and the importance of the Th1 phenotype in the VRP adjuvant effect. We are currently evaluating both the role of Th1 $\mathrm{CD}^{+} \mathrm{T}$ cells in the VRP adjuvant effect and the capacity of various subsets of DCs isolated from the DLN of VRP-infected animals to stimulate co-cultured, antigen-specific CD8 ${ }^{+} \mathrm{T}$ cells, in an attempt to define the mechanisms of T cell activation in the VRP system [ 45 , 46].

Our studies clearly demonstrate that VRP possess intrinsic T cell adjuvant activity; however, the question of whether our experimental system is optimized for T cell activation has not been fully addressed. The inoculation regimen utilized in these studies was based upon our experience utilizing VRP to induce serum IgG responses directed against VRP-expressed antigens. However, the optimal dosing schedule for the induction of T cell adjuvant activity may differ from than that for serum antibody responses. We are actively pursuing dosing schedules and additional methods to further augment the VRP T cell adjuvant effect.

One such method presented here is the utilization of VRP as adjuvants in combination with the known T cell adjuvant, CpG DNA. Our studies demonstrated stronger T cell adjuvant effects following co-delivery of both VRP and CpG together, as compared to delivery of either adjuvant alone. Synergy has been documented following simultaneous delivery of TLR agonists in terms of either proinflammatory cytokine production or T cell activation [47-50]. While a direct role for TLR signaling in alphavirus recognition has yet to be fully clarified, we hypothesized that VRP infection may act synergistically with CpG DNA to further activate cell mediated immunity. However, increased CD8 ${ }^{+} \mathrm{T}$ cell responses following co-delivery of VRP and CpG DNA in the presence of protein antigen appeared to be additive as opposed to synergistic. We are currently evaluating the signaling pathways and cytokine responses activated following delivery of VRP in the presence and absence of CpG DNA in an attempt to further characterize the mechanism/s of immune induction in this system. It is possible that VRP- and CpG-induced signaling occurs in distinct temporal waves, and delivery of VRP and $\mathrm{CpG}$ in a different temporal fashion may provide a synergistic effect. In support of this idea, the kinetics of proinflammatory cytokine production in the DLN appeared to differ between VRP and CpG DNA, with VRP-induced responses peaking approximately 18 hours prior to the peak induced by CpG DNA (Thompson et al., In Press). We are currently evaluating the stimulatory effect of VRP in the presence of CpG DNA, as well as other TLR ligands, when delivered either simultaneously or consecutively. 
Nonmucosal VRP delivery resulted in a significant increase in the proportion of $\mathrm{CD} 8^{+} \mathrm{T}$ cells in the nasal mucosa, suggesting that VRP infection promotes the mobilization of CD8 ${ }^{+}$ $\mathrm{T}$ cells into the mucosal compartment. One possible explanation for this result is that VRP delivery induces TCR-independent migration of $\mathrm{CD} 8^{+} \mathrm{T}$ cells into the mucosal compartment. An alternative explanation is that the increase in mucosal $\mathrm{CD} 8^{+} \mathrm{T}$ cells in the mucosal compartment is in fact due to the influx of antigen-specific cells, specific for antigens other than OVA. While VRP preparations are purified over a sucrose gradient, "contaminating" proteins present in VRP preparations, or normal antigens cycling through the VRP-infected lymph node, may be present at levels sufficient for such proteins to serve as an antigen. VRP may in turn adjuvant the antigen-specific $\mathrm{CD} 8^{+} \mathrm{T}$ cell response to these contaminating and/or natural antigens, accounting for $\mathrm{CD} 8^{+}$cell influx into the mucosal compartment. Additional experiments will be required to distinguish between these possibilities. Antigen-independent mucosal migration may be evaluated by determining the ability VRP to induce mucosal migration of adoptively transferred $\mathrm{CD} 8^{+} \mathrm{T}$ cells with a specificity distinct from that of the immunizing antigen. Regardless of mechanism, it will be important to determine whether this property is unique to the nasal mucosa, or if other mucosal surfaces likewise harbor increased numbers of $\mathrm{CD} 8^{+} \mathrm{T}$ cells.

Activation of mucosal IgA responses following nonmucosal VRP delivery has also been observed [29, 51, 52]. Interestingly, IgA antibodies were first produced in the peripheral draining lymph node, consistent with a model in the DLN plays a role in the inductive process following nonmucosal VRP delivery (Thompson et al., In Press). Characterization of the VRP DLN revealed a population of B cells with increased $a_{4} \beta_{7}$ integrin expression and the presence of mucosal addressin cellular adhesion molecule-1 (MAdCAM-1) on the high endothelial venules, suggesting a role for the mucosal homing receptor interactions in VRP-induced mucosal antibody activation (Thompson et al., In Press). CD8 ${ }^{+} \mathrm{T}$ cells present in the VRP DLN also upregulated the $\alpha_{4} \beta_{7}$ integrin, by approximately 3 -fold. In this context, it is of interest that the $\alpha_{4} \beta_{7}$ integrin is upregulated on antigen-specific, IFN- $\gamma$-secreting cells both in the DLN and at the vaginal mucosal surface [53] as well as on IgA-secreting cells in the vaginal mucosal surface [54] following nonmucosal prime and mucosal boost of an alphavirus replicon chimera containing a VEE replicon RNA, providing additional support for this pathway in alphavirus replicon-induced mucosal $\mathrm{T}$ cell activation. Further experimentation, such as VRP adjuvant experiments in $\beta_{7}$ integrin knock out mice [55], will be required to definitively implicate of this pathway in VRP-induced mucosal immunity; however, we speculate that the $\alpha_{4} \beta_{7}$ integrin pathway plays a significant role in mucosal lymphocyte migration in the alphavirus adjuvant system(s).

In summary, we describe for the first time, the ability of VRP to augment CD8 $8^{+} \mathrm{T}$ cell responses to co-delivered antigen alone and in concert with a TLR agonist. To our knowledge, this is the first demonstration of $\mathrm{T}$ cell adjuvant activity with alphavirus vectors. Much of the VRP-induced activation in the presence of CpG DNA appeared to occur downstream of antigen processing, as increased immunity was observed following delivery of a peptide antigen. Additionally, VRP delivery resulted in increased homing of $\mathrm{CD} 8^{+} \mathrm{T}$ cells into the mucosal compartment, possibly via the mucosal homing receptor. These studies provide a framework which should allow for the identification of the critical viral factors and signaling pathways which are responsible for the activation of $\mathrm{T}$ cell responses to co-delivered antigens. In turn, such knowledge could lead to more efficacious vaccines based on viral vectors.

\section{Acknowledgments}

We thank Nancy Davis for critical review of the manuscript, and members of the Carolina Vaccine Institute for helpful discussions. We acknowledge Martha Collier for preparation of VRP utilized in these studies. This work 
was supported by grants from the National Institutes of Allergy and Infectious Diseases/National Institutes of Health: P01-AI046023 (to R.E.J.), R01-AI051990 (to R.E.J.), U01-AI070976 (to R.E.J.), and T32-AI007419 (to J.M.T.)

\section{References}

1. Andre FE. Vaccinology: past achievements, present roadblocks and future promises. Vaccine. 2003; 21(7-8):593-95. [PubMed: 12531323]

2. Plotkin SA. Immunologic correlates of protection induced by vaccination. Pediatr Infect Dis J. 2001; 20(1):63-75. [PubMed: 11176570]

3. Heeney JL, Plotkin SA. Immunological correlates of protection from HIV infection and disease. Nat Immunol. 2006; 7(12):1281-4. [PubMed: 17110946]

4. Letvin NL. Progress and obstacles in the development of an AIDS vaccine. Nat Rev Immunol. 2006; 6(12):930-39. [PubMed: 17124514]

5. Rayner JO, Dryga SA, Kamrud KI. Alphavirus vectors and vaccination. Rev Med Virol. 2002; 12(5):279-96. [PubMed: 12211042]

6. Lundstrom K. Alphavirus-based vaccines. Curr Opin Mol Ther. 2002; 4(1):28-34. [PubMed: 11883692]

7. Lundstrom K. Alphavirus vectors for vaccine production and gene therapy. Expert Rev Vaccines. 2003; 2(3):447-59. [PubMed: 12903809]

8. Riezebos-Brilman A, Mare Ad, Bungener L, Huckriede A, Wilschut J, Daemen T. Recombinant alphaviruses as vectors for anti-tumour and anti-microbial immunotherapy. Journal of Clinical Virology. 2006; 35(3):233-43. [PubMed: 16448844]

9. Schlesinger S, Dubensky TW. Alphavirus vectors for gene expression and vaccines. Current Opinion in Biotechnology. 1999; 10(5):434-39. [PubMed: 10508626]

10. Polo JM, Gardner JP, Ji Y, Belli BA, Driver DA, Sherrill S, et al. Alphavirus DNA and particle replicons for vaccines and gene therapy. Dev Biol (Basel). 2000; 104:181-5. [PubMed: 11713818]

11. Davis, NL.; Johnston, RE. RNA Virus Replicon Vaccines. In: Levine, MM.; Kaper, JB.; Rappuoli, R.; Liu, MA.; Good, MF., editors. New Generation Vaccines. 3. New York: Marcel Dekker; 2004. p. 337-51.

12. Frolov I, Hoffman TA, Pragai BM, Dryga SA, Huang HV, Schlesinger S, et al. Alphavirus-based expression vectors: Strategies and applications. Proceedings of the National Academy of Sciences. 1996; 93(21):11371-77.

13. Strauss JH, Strauss EG. The alphaviruses: gene expression, replication, and evolution. MicrobiolRev. 1994; 58(3):491-562.

14. Pushko P, Parker M, Ludwig GV, Davis NL, Johnston RE, Smith JF. Replicon-Helper Systems from Attenuated Venezuelan Equine Encephalitis Virus: Expression of Heterologous Genes in Vitro and Immunization against Heterologous Pathogens in Vivo. Virology. 1997; 239(2):389_ 401. [PubMed: 9434729]

15. Burkhard MJ, Valenski L, Leavell S, Dean GA, Tompkins WAF. Evaluation of FIV proteinexpressing VEE-replicon vaccine vectors in cats. Vaccine. 2002; 21(3-4):258-68. [PubMed: 12450701]

16. Dong M, Zhang PF, Grieder F, Lee J, Krishnamurthy G, VanCott T, et al. Induction of Primary Virus-Cross-Reactive Human Immunodeficiency Virus Type 1-Neutralizing Antibodies in Small Animals by Using an Alphavirus-Derived In Vivo Expression System. J Virol. 2003; 77(5):3119_ 30. [PubMed: 12584337]

17. Davis NL, Caley IJ, Brown KW, Betts MR, Irlbeck DM, McGrath KM, et al. Vaccination of macaques against pathogenic simian immunodeficiency virus with Venezuelan equine encephalitis virus replicon particles. J Virol. 2000; 74(1):371-8. [PubMed: 10590126]

18. Davis NL, West A, Reap E, MacDonald G, Collier M, Dryga S, et al. Alphavirus replicon particles as candidate HIV vaccines. IUBMB Life. 2002; 53(4-5):209-11. [PubMed: 12120997]

19. Johnston RE, Johnson PR, Connell MJ, Montefiori DC, West A, Collier ML, et al. Vaccination of macaques with SIV immunogens delivered by Venezuelan equine encephalitis virus replicon 
particle vectors followed by a mucosal challenge with SIVsmE660. Vaccine. 2005; 23(42):496979. [PubMed: 16005121]

20. Braciale TJ, Morrison LA, Sweetser MT, Sambrook J, Gething MJ, Braciale VL. Antigen presentation pathways to class I and class II MHC-restricted T lymphocytes. Immunol Rev. 1987; 98:95-114. [PubMed: 2443444]

21. Gromme M, Neefjes J. Antigen degradation or presentation by MHC class I molecules via classical and non-classical pathways. Molecular Immunology. 2002; 39(3-4):181-202. [PubMed: 12200050]

22. Zhang Y, Williams DB. Assembly of MHC class I molecules within the endoplasmic reticulum. Immunol Res. 2006; 35(1-2):151-62. [PubMed: 17003517]

23. Rock KL, Shen L. Cross-presentation: underlying mechanisms and role in immune surveillance. Immunological Reviews. 2005; 207(1):166-83. [PubMed: 16181335]

24. Cresswell P, Ackerman AL, Giodini A, Peaper DR, Wearsch PA. Mechanisms of MHC class Irestricted antigen processing and cross-presentation. Immunological Reviews. 2005; 207(1):14557. [PubMed: 16181333]

25. Akira S, Uematsu S, Takeuchi O. Pathogen Recognition and Innate Immunity. Cell. 2006; 124(4): 783-801. [PubMed: 16497588]

26. Iwasaki A, Medzhitov R. Toll-like receptor control of the adaptive immune responses. Nat Immunol. 2004; 5(10):987-95. [PubMed: 15454922]

27. Durand V, Wong SYC, Tough DF, Le Bon A. Shaping of adaptive immune responses to soluble proteins by TLR agonists: A role for IFN-alpha/beta. Immunol Cell Biol. 2004; 82(6):596-602. [PubMed: 15550117]

28. Durand V, Wong SY, Tough DF, Le Bon A. IFN-alpha/beta-dependent cross-priming induced by specific toll-like receptor agonists. Vaccine. 2006; 24(Suppl 2):S2-22-3. [PubMed: 16823911]

29. Thompson JM, Whitmore AC, Konopka JL, Collier ML, Richmond EMB, Davis NL, et al. Mucosal and systemic adjuvant activity of alphavirus replicon particles. PNAS. 2006; 103(10): 3722-27. [PubMed: 16505353]

30. MacDonald GH, Johnston RE. Role of Dendritic Cell Targeting in Venezuelan Equine Encephalitis Virus Pathogenesis. The Journal of Virology. 2000; 74(2):914-22.

31. Davis NL, Caley IJ, Brown KW, Betts MR, Irlbeck DM, McGrath KM, et al. Vaccination of Macaques against Pathogenic Simian Immunodeficiency Virus with Venezuelan Equine Encephalitis Virus Replicon Particles. The Journal of Virology. 2000; 74(1):371-78.

32. Grieder FB, Davis NL, Aronson JF, Charles PC, Sellon DC, Suzuki K, et al. Specific Restrictions in the Progression of Venezuelan Equine Encephalitis Virus-Induced Disease Resulting from Single Amino Acid Changes in the Glycoproteins. Virology. 1995; 206(2):994-1006. [PubMed: 7856110]

33. Konopka JL, Penalva LO, Thompson JM, White LJ, Beard CW, Keene JD, et al. A Two-Phase Innate Host Response to Alphavirus Infection Identified by mRNP-Tagging In Vivo. PLoS Pathogens. 2007; 3(12):e199. [PubMed: 18215114]

34. Rizzo LV, DeKruyff RH, Umetsu DT. Generation of B cell memory and affinity maturation. Induction with Th1 and Th2 T cell clones. J Immunol. 1992; 148(12):3733-39. [PubMed: 1351086]

35. Boom WH, Liano D, Abbas AK. Heterogeneity of helper/inducer T lymphocytes. II. Effects of interleukin 4- and interleukin 2-producing T cell clones on resting B lymphocytes. J Exp Med. 1988; 167(4):1350-63. [PubMed: 2965736]

36. Johansson-Lindbom B, Svensson M, Wurbel M-A, Malissen B, Marquez G, Agace W. Selective Generation of Gut Tropic T Cells in Gut-associated Lymphoid Tissue (GALT): Requirement for GALT Dendritic Cells and Adjuvant. J Exp Med. 2003; 198(6):963-69. [PubMed: 12963696]

37. Howard RJ, Craig CP, Trevino GS, Dougherty SF, Mergenhagen SE. Enhanced humoral immunity in mice infected with attenuated Venezuelan equine encephalitis virus. J Immunol. 1969; 103(4): 699-707. [PubMed: 4186914]

38. Craig CP, Reynolds SL, Airhart JW, Staab EV. Alterations in immune responses by attenuated Venezuelan equine encephalitis vaccine. I. Adjuvant effect of VEE virus infection in guinea pigs. $J$ Immunol. 1969; 102(5):1220-7. [PubMed: 4181548] 
39. Hidmark AS, Nordstrom EKL, Dosenovic P, Forsell MNE, Liljestrom P, Karlsson Hedestam GB. Humoral Responses against Coimmunized Protein Antigen but Not against Alphavirus-Encoded Antigens Require Alpha/Beta Interferon Signaling. J Virol. 2006; 80(14):7100-10. [PubMed: 16809315]

40. Moran TP, Collier M, McKinnon KP, Davis NL, Johnston RE, Serody JS. A Novel Viral System for Generating Antigen-Specific T Cells. The Journal of Immunology. 2005; 175(5):3431-38. [PubMed: 16116238]

41. Zhao X, Deak E, Soderberg K, Linehan M, Spezzano D, Zhu J, et al. Vaginal Submucosal Dendritic Cells, but Not Langerhans Cells, Induce Protective Th1 Responses to Herpes Simplex Virus-2. J Exp Med. 2003; 197(2):153-62. [PubMed: 12538655]

42. Itano AA, McSorley SJ, Reinhardt RL, Ehst BD, Ingulli E, Rudensky AY, et al. Distinct Dendritic Cell Populations Sequentially Present Antigen to CD4 T Cells and Stimulate Different Aspects of Cell-Mediated Immunity. Immunity. 2003; 19(1):47-57. [PubMed: 12871638]

43. Filippi C, Hugues S, Cazareth J, Julia V, Glaichenhaus N, Ugolini S. CD4 ${ }^{+}$T Cell Polarization in Mice Is Modulated by Strain-specific Major Histocompatibility Complex-independent Differences within Dendritic Cells. J Exp Med. 2003; 198(2):201-09. [PubMed: 12860929]

44. Itano AA, Jenkins MK. Antigen presentation to naive CD4 T cells in the lymph node. Nat Immunol. 2003; 4(8):733-9. [PubMed: 12888794]

45. Allan RS, Smith CM, Belz GT, van Lint AL, Wakim LM, Heath WR, et al. Epidermal viral immunity induced by CD8alpha+ dendritic cells but not by Langerhans cells. Science. 2003; 301(5641):1925-8. [PubMed: 14512632]

46. Belz GT, Smith CM, Eichner D, Shortman K, Karupiah G, Carbone FR, et al. Cutting edge: conventional CD8 alpha+ dendritic cells are generally involved in priming CTL immunity to viruses. J Immunol. 2004; 172(4):1996-2000. [PubMed: 14764661]

47. Roelofs MF, Joosten LA, Abdollahi-Roodsaz S, van Lieshout AW, Sprong T, van den Hoogen FH, et al. The expression of toll-like receptors 3 and 7 in rheumatoid arthritis synovium is increased and costimulation of toll-like receptors 3,4 , and 7/8 results in synergistic cytokine production by dendritic cells. Arthritis Rheum. 2005; 52(8):2313-22. [PubMed: 16052591]

48. Bagchi A, Herrup EA, Warren HS, Trigilio J, Shin H-S, Valentine C, et al. MyD88-Dependent and MyD88-Independent Pathways in Synergy, Priming, and Tolerance between TLR Agonists. J Immunol. 2007; 178(2):1164-71. [PubMed: 17202381]

49. Napolitani G, Rinaldi A, Bertoni F, Sallusto F, Lanzavecchia A. Selected Toll-like receptor agonist combinations synergistically trigger a T helper type 1-polarizing program in dendritic cells. Nat Immunol. 2005; 6(8):769-76. [PubMed: 15995707]

50. Warger T, Osterloh P, Rechtsteiner G, Fassbender M, Heib V, Schmid B, et al. Synergistic activation of dendritic cells by combined Toll-like receptor ligation induces superior CTL responses in vivo. Blood. 2006; 108(2):544-50. [PubMed: 16537810]

51. LoBue AD, Lindesmith L, Yount B, Harrington PR, Thompson JM, Johnston RE, et al. Multivalent norovirus vaccines induce strong mucosal and systemic blocking antibodies against multiple strains. Vaccine. 2006; 24(24):5220-34. [PubMed: 16650512]

52. Harrington PR, Yount B, Johnston RE, Davis N, Moe C, Baric RS. Systemic, Mucosal, and Heterotypic Immune Induction in Mice Inoculated with Venezuelan Equine Encephalitis Replicons Expressing Norwalk Virus-Like Particles. The Journal of Virology. 2002; 76(2):73042.

53. Gupta S, Janani R, Bin Q, Luciw P, Greer C, Perri S, et al. Characterization of Human Immunodeficiency Virus Gag-Specific Gamma Interferon-Expressing Cells following Protective Mucosal Immunization with Alphavirus Replicon Particles. J Virol. 2005; 79(11):7135-45. [PubMed: 15890953]

54. Goodsell A, Zhou F, Gupta S, Singh M, Malyala P, Kazzaz J, et al. $\beta 7$-integrin-independent enhancement of mucosal and systemic anti-HIV antibody responses following combined mucosal and systemic gene delivery. Immunology. 2008; 123(3):378-89. [PubMed: 17944930]

55. Wagner N, Lohler J, Kunkel EJ, Ley K, Leung E, Krissansen G, et al. Critical role for $\beta 7$ integrins in formation of the gut-associated lymphoid tissue. Nature. 1996; 382(6589):366-70. [PubMed: 8684468] 

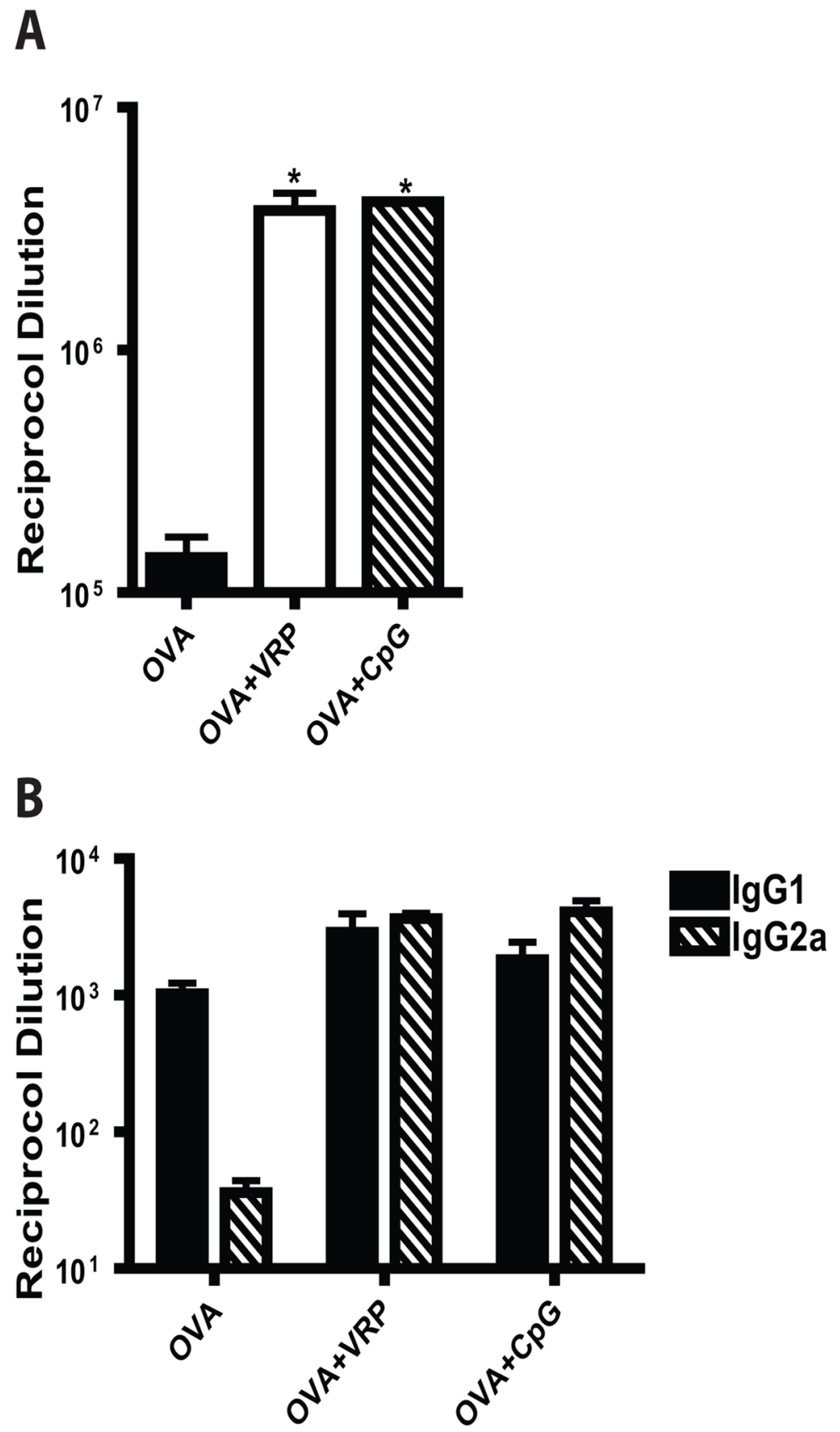

Figure 1. VRP adjuvants promote a balanced Th1/Th2 antibody profile

Groups of eight female Balb/c mice were immunized in the rear footpad at week 0 and week 4 with OVA alone $(10 \mu \mathrm{g})$, or OVA $(10 \mu \mathrm{g})$ mixed with either null VRP $\left(1 \times 10^{5} \mathrm{IU}\right)$ or CpG DNA $(1 \mu \mathrm{g})$. Two weeks following the second inoculation, sera were collected and analyzed for the presence of OVA-specific total IgG antibodies (A) or OVA-specific IgG1 and IgG2a antibodies (B) by ELISA. Values represent the geometric mean \pm SEM. *, p<0.001, compared to OVA alone as determined by ANOVA. 

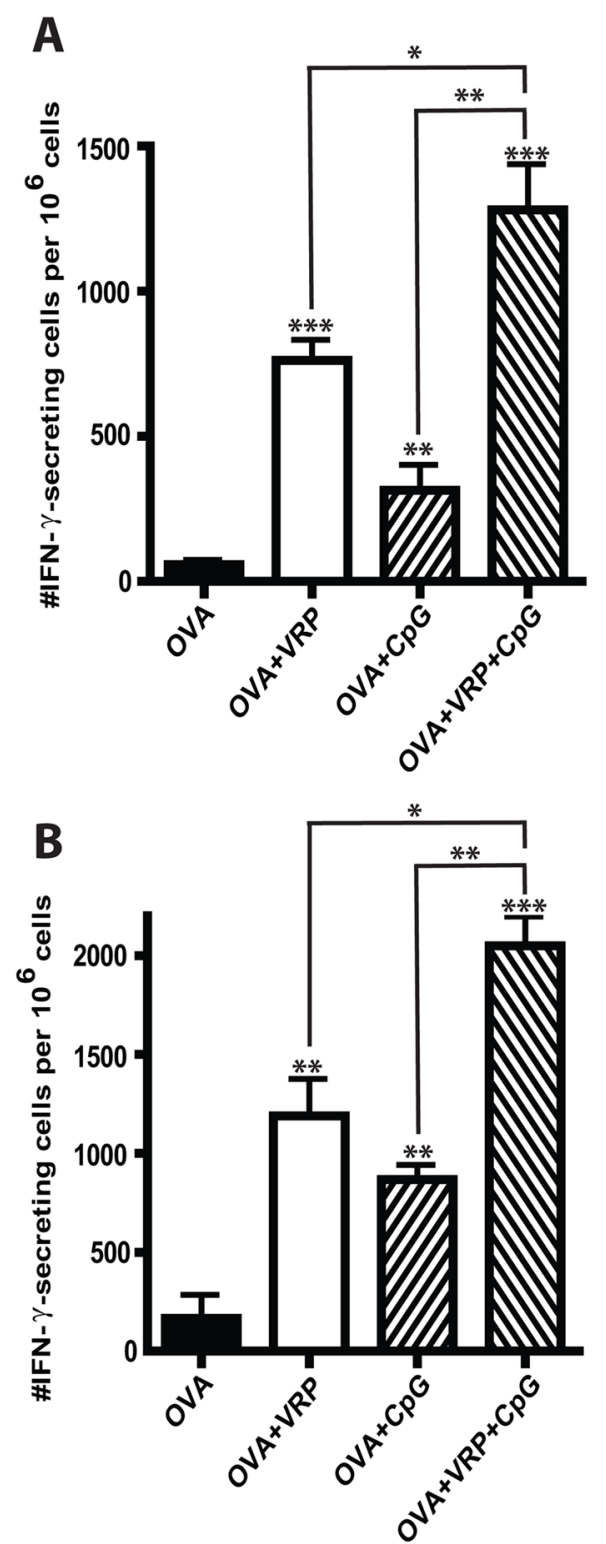

Figure 2. VRP adjuvants promote an increased cellular immune response to co-delivered soluble antigen

Groups of eight female C57BL/6 mice were immunized in the rear footpad at week 0 and week 4 with OVA alone $(100 \mu \mathrm{g})$, or OVA $(100 \mu \mathrm{g})$ mixed with either null VRP $\left(1 \times 10^{5}\right.$ IU), CpG DNA ( $1 \mu \mathrm{g})$, or both null VRP $\left(1 \times 10^{5} \mathrm{IU}\right)$ and CpG DNA $(1 \mu \mathrm{g})$. Two weeks following the second inoculation, splenocytes (A) and nasal lymphocytes (B) were analyzed for the presence of IFN- $\gamma$-secreting cells following stimulation with the OVA class Irestricted peptide in an IFN- $\gamma$ ELISPOT assay. Values represent the geometric mean \pm SEM. *, $\mathrm{p}<0.05 ; * *, \mathrm{p}<0.01 ; * *, \mathrm{p}<0.001$ compared to OVA alone or as indicated, as determined by ANOVA. 


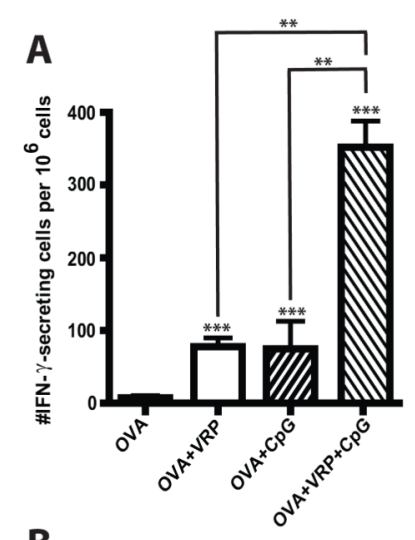

\section{B}
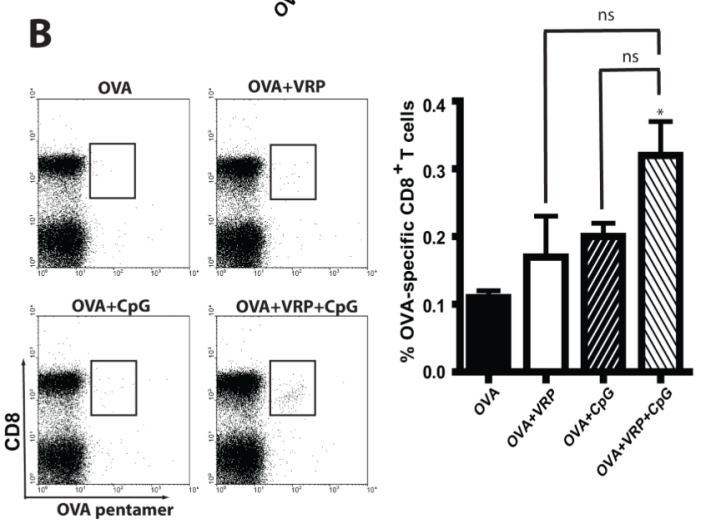

C
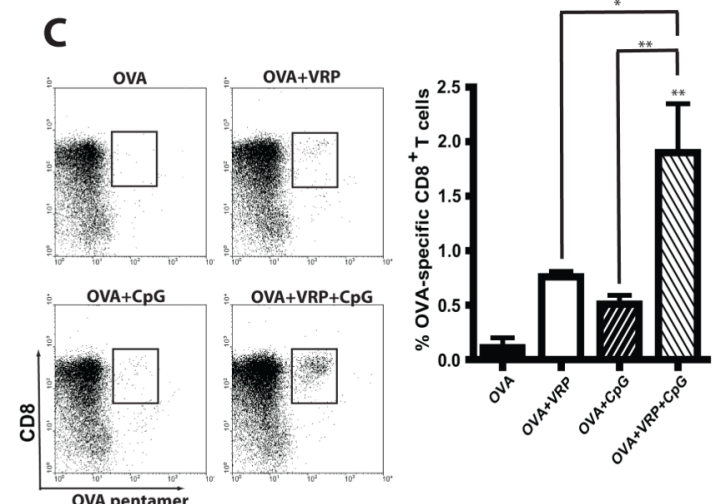

Figure 3. VRP adjuvants promote an increased cellular immune response to co-delivered peptide antigen

Groups of eight female C57BL/6 mice were immunized in the rear footpad at weeks 0, 4, and 8 with OVA peptide (SIINFEKL, $20 \mu \mathrm{g} / 20 \mu \mathrm{g} / 10 \mu \mathrm{g}$ respectively) alone, or mixed with either null VRP $\left(1 \times 10^{5} \mathrm{IU}\right), \mathrm{CpG}$ DNA $(1 \mu \mathrm{g})$, or both null VRP $\left(1 \times 10^{5} \mathrm{IU}\right)$ and CpG DNA $(1 \mu \mathrm{g})$. Two weeks following the last inoculation, splenocytes (A) were analyzed for the presence of IFN- $\gamma$-secreting cells following stimulation with the OVA class I-restricted peptide in an IFN- $\gamma$ ELISPOT assay. Additionally, splenocytes (B) and nasal lymphocytes (C) were analyzed for the presence $\mathrm{pMHC}$-specific $\mathrm{CD}^{+} \mathrm{T}$ cells by pentamer staining. Values represent the geometric mean \pm SEM. ns, not significant; *, p<0.05; **, p<0.01; ***, $\mathrm{p}<0.001$ compared to OVA alone or as indicated, as determined by ANOVA. 

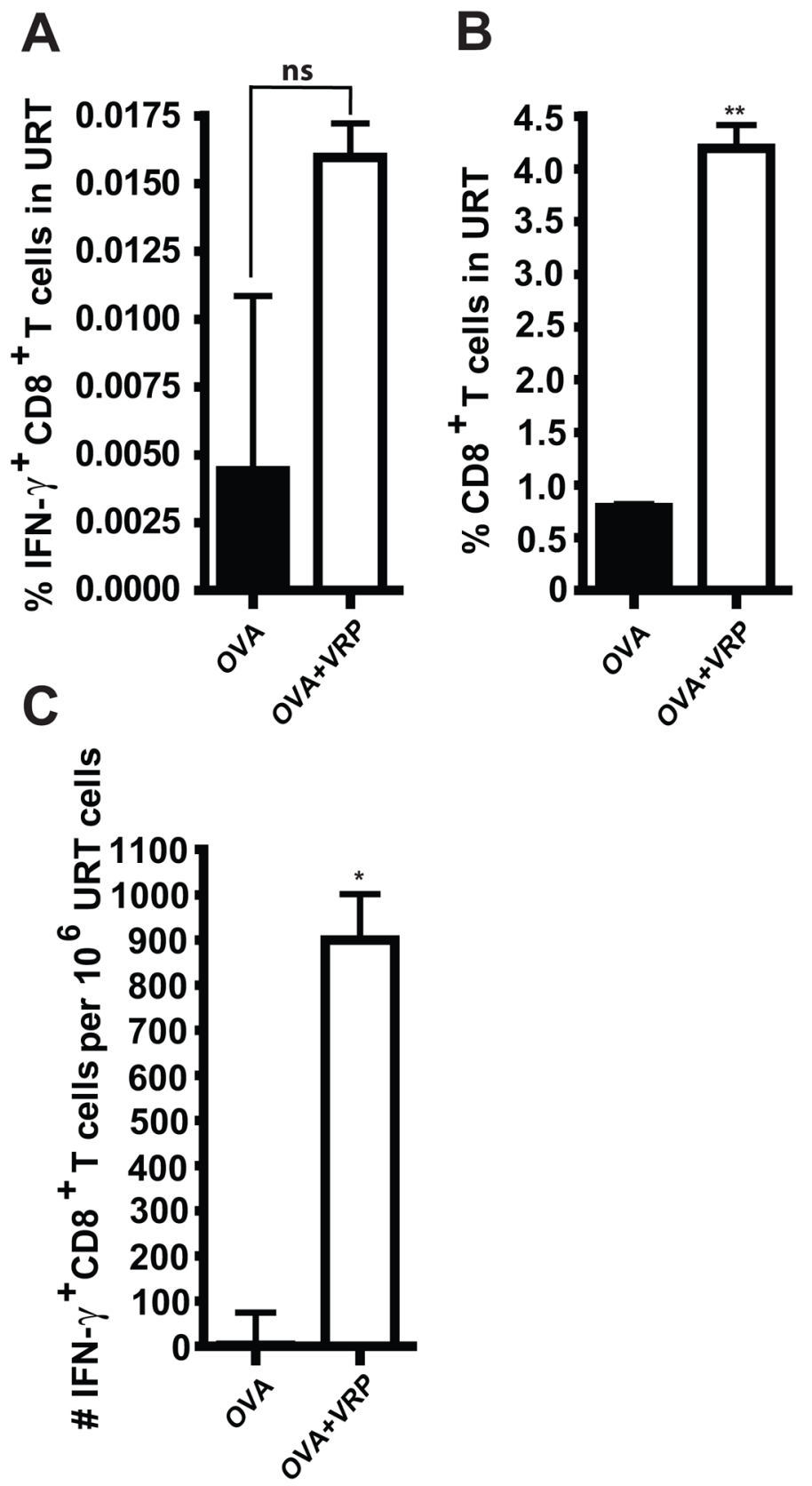

Figure 4. Nonmucosal VRP delivery results in increased numbers of mucosal $\mathrm{CD8}^{+} \mathrm{T}$ cells Groups of eight female Balb/c mice were immunized in the rear footpad at weeks 0 and 4 with OVA alone $(10 \mu \mathrm{g})$, or OVA $(10 \mu \mathrm{g})$ mixed with null VRP $\left(1 \times 10^{5} \mathrm{IU}\right)$. Two weeks following the second inoculation, upper respiratory tract (URT) lymphocytes were evaluated for the presence of IFN- $\gamma^{+} \mathrm{CD} 8^{+} \mathrm{T}$ cells by ICS following in vitro stimulation with the OVA class I-restricted peptide (A). Additionally, both the $\%$ of $\mathrm{CD}^{+} \mathrm{T}$ cells present in the URT (B) and the total number of IFN- $\gamma^{+} \mathrm{CD}^{+} \mathrm{T}$ cells following peptide stimulation were also evaluated at two weeks post boost. Values represent the geometric mean \pm SEM. ns, not significant; *, $\mathrm{p}=0.0286 ; * *, \mathrm{p}=0.0002$ compared to OVA alone, as determined by MannWhitney. 
CD8+ T cells

OVA
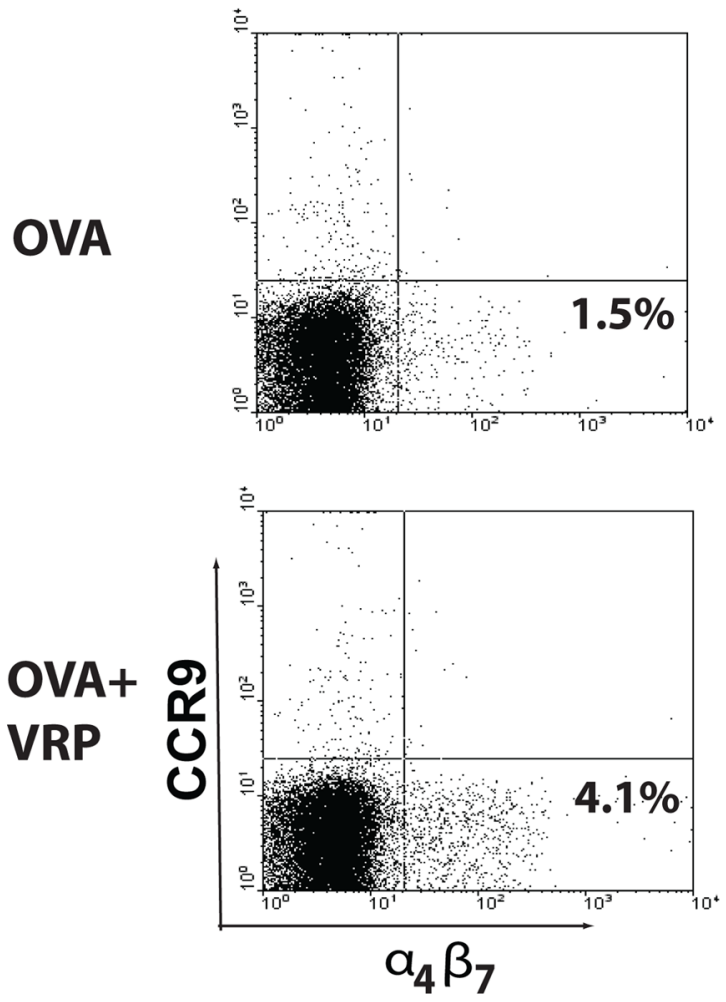

CD4+ T cells
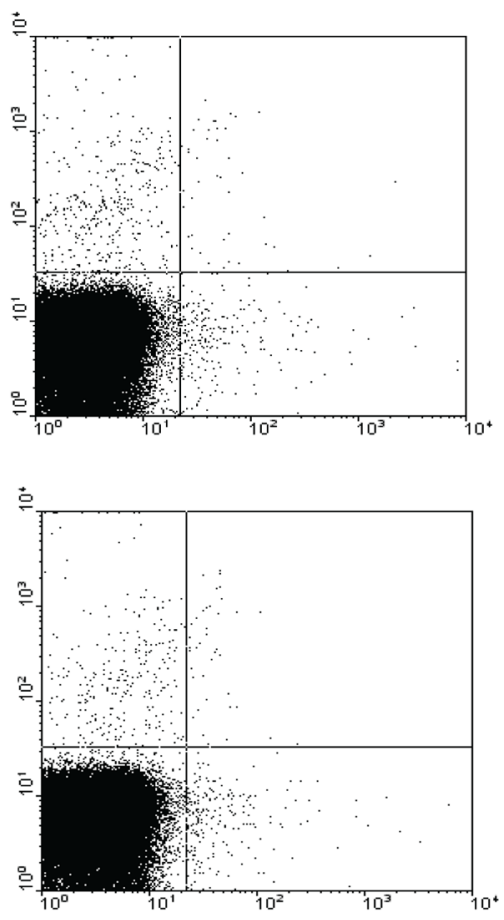

Figure 5. VRP upregulate the mucosal homing receptor on DLN $\mathrm{CD8}^{+} \mathrm{T}$ cells

Groups of female Balb/c mice were immunized in the rear footpads at weeks 0 and 4 with OVA alone $(10 \mu \mathrm{g})$, or mixed with either null VRP $\left(1 \times 10^{5} \mathrm{IU}\right)$. Day 3 following the last inoculation, single cell suspensions were prepared from the DLN and CD4 ${ }^{+}$and CD8+ T cells were analyzed for the presence of the $\alpha_{4} \beta_{7}$ integrin and CCR9 by flow cytometry. Shown are the proportion of $a_{4} \beta_{7}$ integrin positive cells. 